\title{
Techno-Economic Assessment of an Air-Multiple PCM Active Storage Unit for Free Cooling Application
}

\author{
Muriel Iten (D)
}

Citation: Iten, M. Techno-Economic Assessment of an Air-Multiple PCM Active Storage Unit for Free Cooling Application. Sustainability 2021, 13, 12936. https://doi.org/10.3390/ su132312936

Academic Editor: Luca Cioccolanti

Received: 8 November 2021

Accepted: 18 November 2021

Published: 23 November 2021

Publisher's Note: MDPI stays neutral with regard to jurisdictional claims in published maps and institutional affiliations.

Copyright: (C) 2021 by the author. Licensee MDPI, Basel, Switzerland. This article is an open access article distributed under the terms and conditions of the Creative Commons Attribution (CC BY) license (https:// creativecommons.org/licenses/by/ $4.0 /)$.
Low Carbon and Resource Efficiency, R\&Di, Instituto de Soldadura e Qualidade, 4415491 Grijó, Portugal; mciten@isq.pt

\begin{abstract}
A latent energy storage (LES) unit is presented in this paper for free space cooling and ventilation application. The unit includes multiple phase change materials (PCM) to advance the thermal performance of common LES units. It is composed by metallic rectangular panels containing commercial paraffins with melting temperatures ranging among $20^{\circ} \mathrm{C}$ and $25^{\circ} \mathrm{C}$ and surrounded by air channels. The average cooling load of the unit corresponds to approximately $1 \mathrm{~kW}$ over $8 \mathrm{~h}$. It fulfils the peak ventilation cooling load during summer of an office building in Portugal. The study provides a techno-economic analysis and the environmental benefits of the LES technology compared to a traditional air conditioning (AC) unit for the cooling and ventilation of an office building. During daytime, the air-multiple PCM unit allows reducing the energy consumption by nearly $200 \mathrm{kWh}$. The full charging of the PMs during nighttime, requires significant energy consumption due to the high air flowrate demand for full solidification. The competitiveness of such units can be achieved by introducing fins into the panels, allowing double the energy savings. In an overall perspective, the unit presents several benefits such as lower initial cost and reduced maintenance requirements (non-use of refrigerants and batteries) that also allows better personal health issues when related to traditional ACs.
\end{abstract}

Keywords: phase change materials; free cooling ventilation; techno-economic analysis; case study

\section{Introduction}

Nonresidential buildings in Europe encompass one fourth of the building stock, with office buildings accounting among the most significant contributors to demand growth [1]. Over the years, there has been a continuous increase in heating, cooling and ventilation (HVAC) systems, particularly in the developing countries, within offices and nonresidential buildings corresponding to the main energy consumption parcel [2]. Hence, developed countries are looking for renewable solutions to secure such needs. This figure is, however, still below the EU target of $20 \%$ energy being produced by renewable sources [3]. Latent energy storages (LES) are commonly used in buildings, jointly with HVAC systems, provided individually and incorporated into construction materials (e.g., construction wall, roof and ground) [4]. In particular, air-PCMs LES applications can provide the required cooling and ventilation demands or reduce the temperature swings within buildings. Such applications are commonly denominated as "free cooling". A differential temperature among the air and the melting of the PCM must range between 3 and $5^{\circ} \mathrm{C}$ to assure enough heat transfer [5]. Therefore, the PCM melting temperature is a critical factor to enhance the buildings performance for different climatic conditions [6]. Several studies on active air- single PCM units applied to free cooling are presented in the literature. Iten et al. [4] present a comprehensive review on the air- PCM application for the air conditioning of buildings. Overall, for free cooling of buildings, such units require careful selection of the PCMs such that the melting and solidification points guarantee a complete charging and discharging process. This depends mostly on local climate conditions. Another important aspect to consider while applying PCMs, is its general low thermal conductivity, usually 
between 0.2 and 0.7 [W/m K] [7]; requiring heat transfer improvement techniques to enhance the charging and discharging rate of energy [8]. Lately, multiple PCMs are stated in the literature as a way to improve LES systems, presenting the following advantages: higher heat transfer rate, particularly during the change of phase [9]; keeping a higher transport temperature difference for the heat transfer process in charging and discharging processes [10]; quicker charging and discharging processes [11]; preserving a steady heat flux from the PCM and the heat carrier fluid [12]; and achieving a maximised storage capacity and melt fraction [13].

LES are mostly analysed on an experimental or numerical dimension, whereas commercial applications remain limited. In fact, it is noted that only in a few of these studies, has an economic analysis been included [14]. Moreover, regarding cooling applications considering PCMs, limited works considers such investigation. For instance, Chaiyat [15] developed a model to perform an economic analysis of an air conditioner assisted with a pack bed of PCM balls in order to improve its efficiency. It has been found that the electrical consumption of the modified air-conditioner could be decreased to around $3.09 \mathrm{kWh} / \mathrm{d}$. The saving cost from the PCM bed could be $9.10 \%$ of $170.03 \mathrm{USD} / \mathrm{y}$, and the payback period corresponded to around 4.15 years. Later, Boccardo et al. [16] investigated the economic performance of thermally active building systems (TABS), radiant ceiling panels with PCM and a traditional all-air system (e.g., variable air volume system) in an open-plan office. Different cooling loads have been studied and the global cost and the payback period of each system has been compared. It was observed that TABS corresponded to the cheapest option. The costs estimated for PCM ceiling scenarios were higher, however, they corresponded to a valid alternative when TABS were not viable (e.g., renovation projects). In addition, for high cooling loads, PCM ceiling panels were a good option as they were only marginally more expensive than the all-air system. Overall, the cooling energy corresponded to the lowest cost component of the global costs (over 30 years), suggesting that the economic focus must be mainly on initial costs, maintenance and replacement in order to obtain substantial economic savings. Recently, the effect of the integration of PCMs into buildings also employing natural or mechanical ventilation has been analysed by Mechouet et al. [17] The application of a mechanical ventilation rate of 6 air change per hour $(\mathrm{ACH})$ with a $6 \mathrm{~mm}$ thick PCM panel allowed to reduce the cooling energy from 6 to $21 \%$ (depending on the climatic zone in Morocco) compared to the use of mineral wool insulation. For instance, in a building located in Marrakech, such a solution, for cooling purposes, corresponded into a dynamic payback period of 11 years.

Overall, there is still a lack of adequate information on real potentials and practical aspects of PCM application in buildings (e.g., techno-economic), namely on independent air-PCM systems to provide cooling of buildings. On this segment, this paper provides a contribution to knowledge by presenting the application of an air-multiple PCM unit for the free cooling ventilation of an office building located in Portugal. The paper focuses on a techno-economic analysis of such unit and a conventional air conditioning system also considering the environmental aspects. This analysis intends to bridge the LES application gap in buildings as other relevant applications. Such standalone analysis corresponds to an essential input for applied research, looking for a higher level of readiness and its market uptake.

\section{Structure of the Work}

The work is structured as displayed in Figure 1. Firstly, the required cooling ventilation, building occupancy and thermal comfort conditions for the case study building are specified (Section 3.1). This will allow sizing the two cooling units: air-multiple PCM (Section 4.1) and the air conditioning (Section 4.2). The sizing of the novel air-multiple PCM unit considers the works of the author as input data, namely: validity of the numerical model in Iten et al. [18], followed by its design in Liu et al. [19]. The presented approach enables the techno-economic analysis, i.e., the focus of this paper (Section 5). This analysis includes the running costs (e.g., energy consumption of required fans and systems) and the 
capital and maintenance costs of the proposed unit and a conventional AC for the cooling ventilation of a case study building. Moreover, the environmental benefits are identified for each unit.

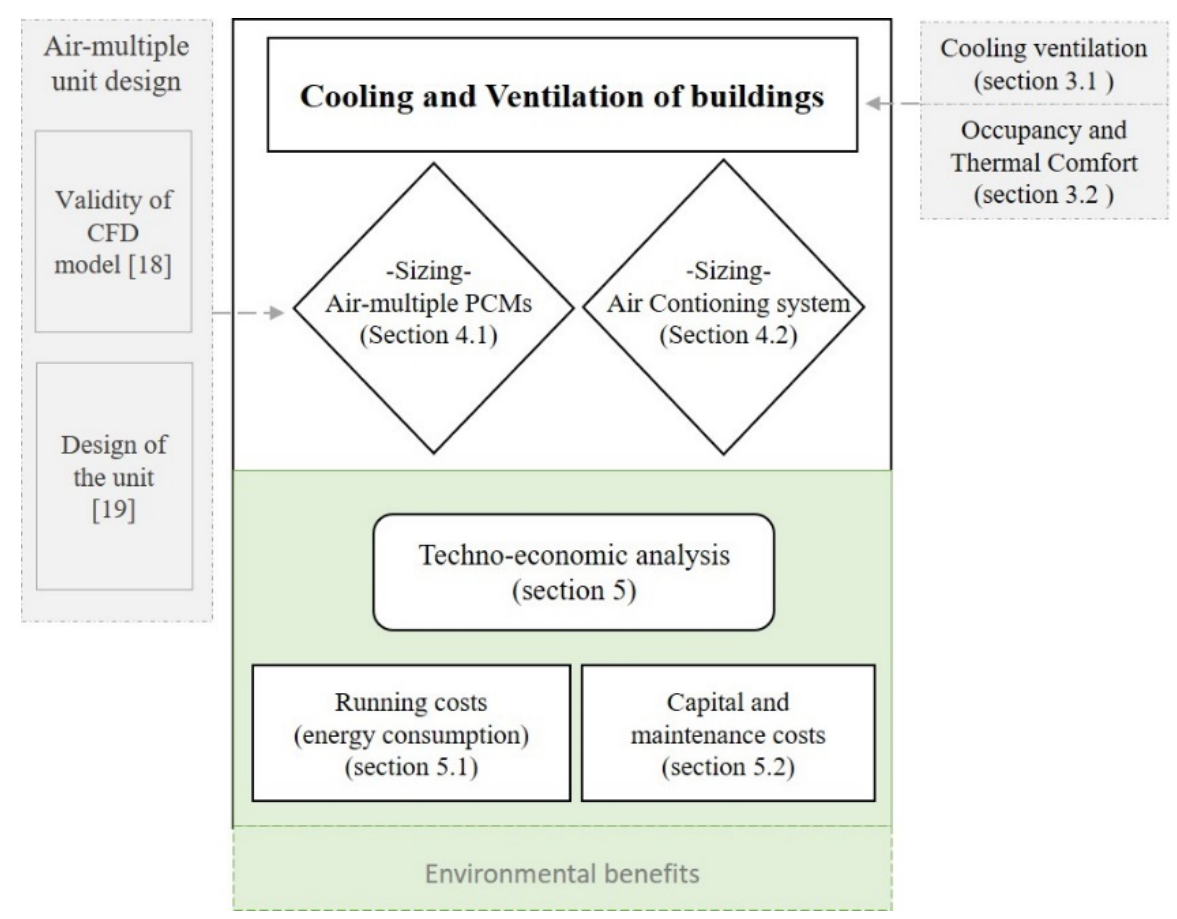

Figure 1. Structure of the work: techno-economic analysis and environmental benefits of air-multiple PCM unit and AC system.

\section{Requirements}

\subsection{Cooling Ventilation Load}

The current work presents a case study of an office building with $200 \mathrm{~m}^{2}$ located in Castelo Branco, Portugal and accommodating 20 occupants. The cooling demand for the case study building is focused only on the occupants, excluding the other factors such as equipment, appliances and infiltrations, in order to provide a comfortable temperature of the fresh air supplied. The recommended air supply for office buildings corresponds to $35 \mathrm{~m}^{3}$ / (h. occupant) according to the Portuguese Directive [20]. Therefore, the total cooling ventilation load required corresponds to $700 \mathrm{~m}^{3} / \mathrm{h}$. Such a flow rate needs to be provided by the fans of the air-multiple PCM unit as well as by the air conditioning system.

\subsection{Occupancy and Thermal Comfort}

The predominant occupancy profile for office buildings is commonly considered from 9:00 to 18:00 [16]. For the thermal comfort, for the adaptive thermal comfort temperatures, the external temperature and the occupant's perceptions have been considered. For conditioned buildings, the limit of comfort conditions corresponds to $30^{\circ} \mathrm{C}$ for an external temperature of $30^{\circ} \mathrm{C}$ [21]. For the sizing of the units, cooling takes place when the external temperature is higher than $30^{\circ} \mathrm{C}$, corresponding to overheating (i.e., discomfort conditions).

\section{Sizing of the Cooling Ventilation Units}

\subsection{Sizing of the Air-Multiple PCM Unit}

(i) Validity of the CFD model [18]

The design of the air-multiple PCM was performed by a computational fluid dynamics (CFD) model using FLUENT 15.0 software. The model has been previously validated by the author in Iten et al. [18] with the experimental data presented in Iten et al. [22,23]. The experimental apparatus included an exhaust fan, an air-PCM unit, a portable air 
conditioner, electrical coils, a data logger, a personal computer (PC) and measurement equipment (thermocouples and anemometer) (Figure 2). The experimental uncertainty has been determined in Iten el. [22] and is presented in Table 1.

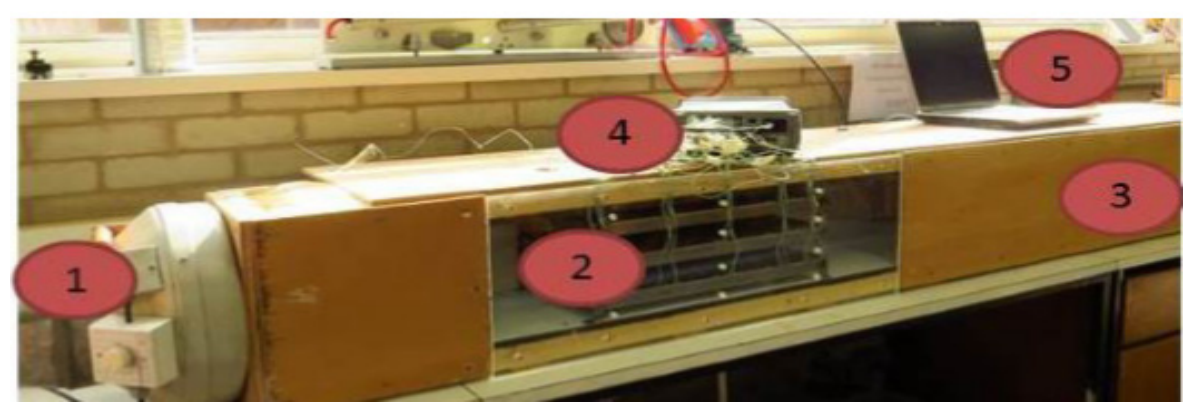

Figure 2. Testing rig (1. Exhaust fan; 2. Air-PCM unit; 3. Heating/Cooling unit; 4. Data logger; 5. Laptop) [23].

Table 1. Experimental uncertainty [23].

\begin{tabular}{ccc}
\hline Parameter & Equipment & Uncertainty \\
\hline PCM temperature & K-type thermocouples, Data logger & $1.3 \%$ \\
Air temperature & K-type thermocouples, Data logger & $1.6 \%$ \\
Air velocity & Anemometer & $0.16 \%$ \\
\hline
\end{tabular}

In the experimental testing, the inlet air temperature has been setup constant at $38^{\circ} \mathrm{C}$ (discharging process) and $12{ }^{\circ} \mathrm{C}$ (charging process), for a constant air inlet velocity of $2.5 \mathrm{~m} / \mathrm{s}$. Such temperatures correspond to extreme daytime temperature (noon to 4 p.m.) and nighttime temperature (midnight to 7 a.m.) in Mediterranean Countries [24]. The initial temperature of the PCM for each testing has been setup at $16^{\circ} \mathrm{C}$ (discharging process) and $30^{\circ} \mathrm{C}$ (charging process). The PCM temperatures have been measured by thermocouples along the panels and at the air outlet and recorded with a data logger until the phase change of the PCM panels were complete. The thermophysical properties of the materials applied into CFD modeling are presented in Table 2.

Table 2. Thermophysical properties of selected materials [22].

\begin{tabular}{|c|c|c|c|c|c|}
\hline \multirow{2}{*}{ Material } & \multirow{2}{*}{$\begin{array}{c}\text { Melting } \\
\text { Temperature } \\
\left({ }^{\circ} \mathrm{C}\right)\end{array}$} & \multicolumn{2}{|c|}{ Density $\left(\mathrm{kg} / \mathrm{m}^{3}\right)$} & \multirow{2}{*}{$\begin{array}{c}\text { Thermal } \\
\text { Conductivity } \\
\left(\mathrm{W} / \mathrm{m} .{ }^{\circ} \mathrm{C}\right)\end{array}$} & \multirow{2}{*}{$\begin{array}{c}\text { Specific Heat } \\
\text { Capacity } \\
\left(\mathrm{kJ} / \mathrm{kg} .{ }^{\circ} \mathrm{C}\right)\end{array}$} \\
\hline & & Solid & Liquid & & \\
\hline PCM & $23-25$ & 880 & 760 & 0.20 & 2000 \\
\hline Steel & - & \multicolumn{2}{|c|}{8030} & 16.27 & 0.502 \\
\hline Air & - & \multicolumn{2}{|c|}{1.23} & 0.02 & 1006 \\
\hline
\end{tabular}

Iten et al. [18], namely, Figures 3 and 4, present the experimental and numerical results for the PCM temperature (last point where phase change takes place) and air outlet temperature (exit of the air channel). Good agreements have been achieved between the experimental and numerical data with a max. error of $2.6 \%$ for the PCM temperature and $1.5 \%$ for the outlet air temperature.

\section{(ii) Design of the unit [19]}

The design criteria of the unit considered the building occupancy and the thermal comfort (as described in Section 3.2). Matching these two criteria allowed to identify the required cooling demand and, more precisely, the required cooling period. Figure 3 displays a typical daily temperature profile during summer in Castelo Branco, Portugal [25] and considered for the design of the unit in Liu et al. [19]. This profile corresponds 
to average daily temperature observed in the Summer, namely between 21 June and 21 September. From Figure 3 it is observed that the PCM panels need to be fully charged (i.e., solidified) during nighttime: 21:00 to 07:00, when night temperature is below the melting temperature. While during daytime, between 11:00 and 18:00, the PCM panels need to be fully discharged (i.e., melted) to provide free cooling to the building. During this period, predominant occupancy is observed, and the external temperature reaches more than $30{ }^{\circ} \mathrm{C}$ (i.e., overheating period).

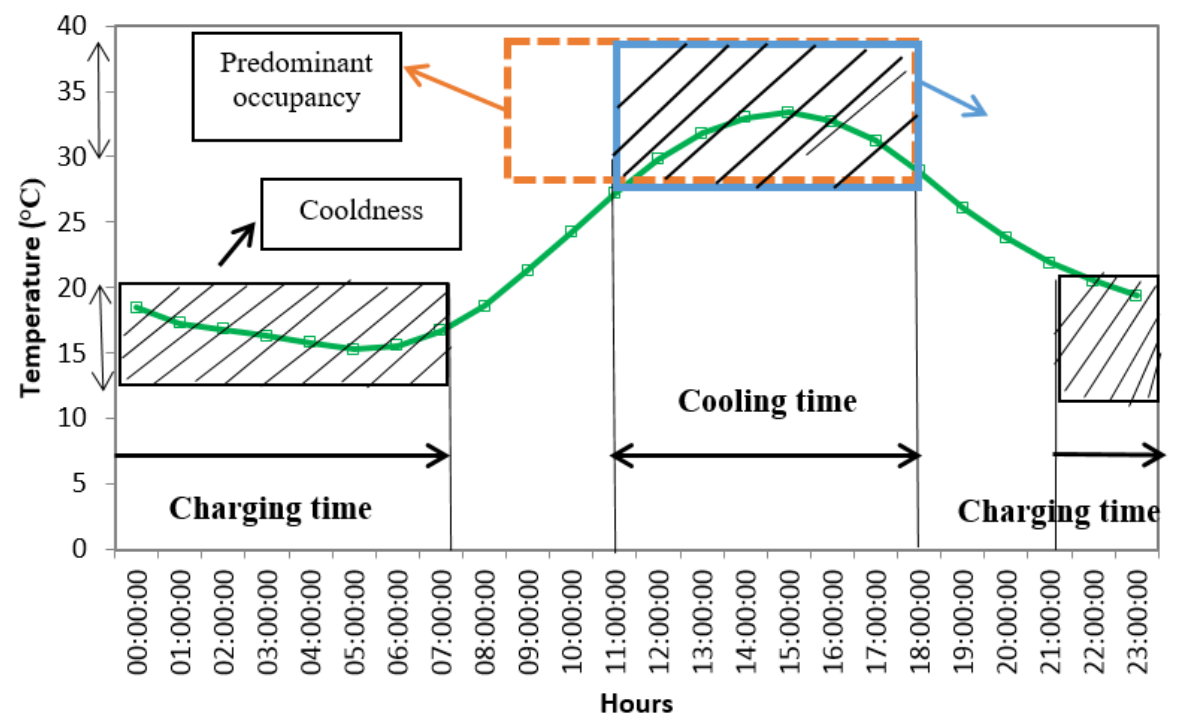

Figure 3. Typical daily temperature profiles for the summer in Castelo Branco, Portugal (Aguiar and Coelho [25]; Liu et al. [19]).

The validated model (transcribed in section $i$ from Iten et al. [18]), has been further extended for the design and optimisation of the air-multiple PCMs unit in Liu et al. [19]. For the multiple PCM unit, in addition to the PCM included in the experimental testing and numerically validated (melting temperature between $23^{\circ} \mathrm{C}$ and $25^{\circ} \mathrm{C}$ ), a PCM with a melting temperature between 18 and $20^{\circ} \mathrm{C}$ was selected and accurately integrated in the model as it presents same structural and physical behavior. The addition of a PCM with inferior melting temperature permitted that a temperature difference sustained between the PCM and the air in the flow direction, enhancing the heat exchange rate. Furthermore, a PCM with a melting point at $20^{\circ} \mathrm{C}$ fits with the occupant's comfort temperatures as well as with the local climatic conditions for charging and discharging. Each panel of the unit was filled halfway with one PCM and another half the other. The optimisation of the unit was studied by the author and reported in Liu et al. [19]. The optimisation focused on the dimensions of the panels and on the charging and discharging flowrates to assure that a full cycle was undertaken for the storage and release of coolness. The optimal dimensions and flowrates are listed in Table 3. For these optimised variables, the hourly delivered cooling load varies from 0.4 to $1.46 \mathrm{~kW}$ with an average load corresponding to $1.1 \mathrm{~kW}$ [19].

Table 3. Multiple PCM unit details and operating conditions [19].

$\begin{array}{cc}\text { Total PCM mass } & 102.6 \mathrm{~kg} \\ \text { Mass per panel } & 34.2 \mathrm{~kg}(17.1 \mathrm{~kg} / \text { PCM type }) \\ \text { PCM panels height } & 0.03 \mathrm{~m} \\ \text { PCM panels length } & 1.5 \mathrm{~m} \\ \text { PCM panels width } & 1 \mathrm{~m} \\ \text { charging air mass flow rate } & 734.7 \mathrm{~m}^{3} / \mathrm{h} \\ \text { harging air mass flow rate } & 5877.6 \mathrm{~m}^{3} / \mathrm{h} \\ \text { Average cooling load } & 1.1 \mathrm{~kW}\end{array}$


Considering 20 occupants in the case study building, for a fresh air flowrate of $700 \mathrm{~m}^{3} / \mathrm{h}$ (described in Section 3.1) and guaranteeing the comfort temperatures (below $30{ }^{\circ} \mathrm{C}$-Section 3.2), the required cooling load and ventilation corresponds to $1 \mathrm{~kW}$. As the required cooling load for the case study building is assured by the air-multiple PCM presented in Table 3, the techno-economic analysis has been carried out for this storage unit.

\subsection{Sizing of the Air Conditioning System}

A convectional cooling unit has been identified for this study aiming at the comparison with the PCMs unit, considering a cooling load of $1 \mathrm{~kW}$. The AC unit corresponds to a ceiling cassette with a four-way blow system and a centrifugal fan, fulfilling the fresh air requirements $\left(734.7 \mathrm{~m}^{3} / \mathrm{h}\right)$. The energy consumption of the fan is determined by Equation (3), further detailed.

\section{Techno-Economic Analysis}

A techno-economic analysis has been undertaken by determining the running costs (i.e., energy consumption), capital and maintenance costs of the storage unit and the conventional AC unit followed by the payback time.

\subsection{Running Costs (Energy Consumption)}

A fan has been selected, considering the flow rate the air duct provided by the air multiple PCM unit: $734.7 \mathrm{~m}^{3} / \mathrm{h}$ and $5877.5 \mathrm{~m}^{3} / \mathrm{h}$ for the daytime (e.g., discharging) and nighttime (e.g., charging), respectively. The total pressure drop, related to the frictional pressure loss, corresponded to $30 \mathrm{~Pa}$ (e.g., discharging) and $484.38 \mathrm{~Pa}$ (e.g., charging) [19]. In order to fulfil such requirements, a fan ranging from $0.036 \mathrm{~kW}$ (e.g., discharging) to $0.853 \mathrm{~kW}$ (e.g., charging) has been selected.

\section{(i) Air-multiple PCM}

The total energy consumption of the air-multiple unit is associated with the operation of a fan $\left(W_{f a n}\right)$ at the two flow rates (charging and discharging) and consequently to the two powers $\left(P_{f a n, 1}\right.$ and $\left.P_{f a n, 2}\right)$. Hence, its consumption corresponds to the sum of the fan operating at lower power $(f a n, 1)$ over $8 \mathrm{~h}$ (daytime) and at a higher power $(f a n, 2)$ over $9 \mathrm{~h}$ (nighttime) for 65 days (June-September) as follows:

$$
W_{f a n}=\left(P_{f a n, 1} \times t\right)_{\text {charging }}+\left(P_{f a n, 2} \times t\right)_{\text {discharging }}
$$

(ii) Air conditioning system (AC)

The energy consumption of the AC unit $\left(W_{A C}\right)$ and the fan $\left(W_{f a n}\right)$, running $8 \mathrm{~h}$ a day over 65 days (June-September), are determined by Equations (2) and (3) as follows:

$$
\begin{aligned}
& W_{A C}=P_{A C} \times t \\
& W_{f a n}=P_{f a n} \times t
\end{aligned}
$$

\subsection{Capital and Maintenance Costs}

The proposed air-multiple PCM unit comprises commercially available PCMs (e.g., paraffins) fairly inexpensive (7 GBP/kg) [26]. Paraffins present good combability with most materials, namely with metallic container. Hence, the cost of its encapsulation is highly competitive. Such PCMs also suffer from insignificant supercooling or phase segregation, presenting a longstanding stability. This ensures that the PCM performs in good conditions after many solidification and melting series. Overall, the PCMs unit requires no significant maintenance, ensuing substantial cost reduction. The two commercial paraffins encapsulated into rectangular panels make up a total volume of $0.045 \mathrm{~m}^{3}$ and weight of $102.6 \mathrm{~kg}$. Apart from the paraffins, the proposed unit includes its encapsulation, fan and pipework. The encapsulation comprises rectangular containers of steel and introduced 
into a rectangular ducting. The space and labor of installation are considered to be similar for both systems and therefore are not included in the analysis (e.g., interconnection with building, external unit).

The air multiple PCMs unit and the AC present yearly energy consumption of 517.67 kWh and $219.02 \mathrm{kWh}$, respectively. Table 4 shows that the PCM unit presents a considerable inferior energy consumption $(18.67 \mathrm{kWh})$ than the traditional AC $(219.02 \mathrm{kWh})$ throughout the day. This enables a saving of $200.35 \mathrm{kWh}$ per year relating to the AC unit. The proposed unit, however, presents a predominant energy consumption owing to the fan operation during the period. Nevertheless, the PCM unit involves a lower capital cost than the AC system. It also presents a lower maintenance cost as it requires mostly the cleanness of the air filters. In Portugal, considering a bi-hourly electricity package $(0.1890 \mathrm{GBP} / \mathrm{kWh}$ : daytime; 0.0978 GBP/kWh: nighttime [27]), the yearly cost corresponds to GBP 52.3 and GBP 41.4 for the PCM unit and AC, respectively. To promote the competitiveness of the unit, the charging process of the PCMs requires further improvement during night-time. For instance, improving the heat transfer inside the PCM panels will require less air flow rate for its full charging and so to reduce the fan size and running costs. The insertion of fins in similar PCM panels, following Stritih's study [28], has revealed reduced natural convection (e.g., dominant phenomena during melting), however, a better heat transfer over solidification, enabling to decrease the solidification period by $40 \%$. Considering such figures, three air-multiple PCM scenarios have been analysed: (i) current unit, (ii) improved unit (including fins and considering 40\% solidification time reduction according Stritih [28]) and (iii) ideal unit (solidification time is similar with the melting time). The analysis has been performed for the common 20 year lifetime of ACs. Figure 4 presents the total cost (investment, running and maintenance) of each unit over the lifetime and the savings achieved by the three units in comparison to the traditional AC system.

It is observed that the energy savings for each air-multiple PCM unit increases over the years. For instance, for the improved unit-including fins-after 20 years, it presents the double of savings compared to the current (proposed) unit. Regarding the ideal unit (melting time same as solidification time), the savings can be greater than 11 times compared to a traditional AC system. Such ideal solutions are, however, complex to achieve, because while high conductive elements are introduced within the PCMs panels (such as fins) to reduce solidification time, they compromise the natural convection during melting. Given that the viability of such technology relies mostly on the running costs (Table 4), such analysis and respective results highlight how such measures can have impact throughout its lifetime. Overall, this analysis shows that such units can become economically competitive with the inclusion of fins by significantly improving the charging process. Moreover, they benefit from the maintenance point of view as during their lifetime this is related mostly the cleanness of air filters.

In addition, any air-multiple PCM unit for free cooling presents several environmental benefits such as no need of refrigerants (e.g., CFCs, HFCs and HCFCs) that are significant responsible for the ozone depletion and applied into AC. Such refrigerants also involve cautious management for the AC pull to pieces for recycling or deposited in landfills. The US Environmental Protection Agency such as further environmental agencies are lawful to execute fines up to GBP 16000 for failing to conform with the present legislation. Commonly, dedicated businesses are responsible for handling the discarding of AC units. Indeed, AC can also guarantee individual health issues, however, failing with satisfactory maintenance, they can be a health threat. Muddy components can permit allergens, insecticides such as other elements to enter from the outside atmosphere, compromising the indoor air environment. In addition, the extended contact to such contaminants can affect health difficulties, counting allergies, asthma and eye, nose and throat irritation. 
Table 4. Equipment capital and running cost.

\begin{tabular}{|c|c|c|}
\hline & Air-Multiple PCM Unite & \multirow{2}{*}{ Traditional AC System } \\
\hline & Night-Time & \\
\hline Capital cost & $\begin{array}{c}\text { PCMs: GBP } 718.2 \\
\text { Steel encapsulation: GBP } 313 \\
\text { Air duct: GBP } 107 \\
\text { Fans: GBP } 1100.5\end{array}$ & $\begin{array}{l}\text { Ceiling cassette system: } \\
\text { GBP } 2099 \\
\text { Fan: GBP } 254.2\end{array}$ \\
\hline Maintenance cost & $\begin{array}{c}\text { GBP } 15 \\
\text { (yearly: cleanliness of air-filters) }\end{array}$ & $\begin{array}{c}\text { GBP 70 } \\
\text { (yearly: hygiene of the } \\
\text { coils, air-filters and leaks } \\
\text { detection/remediation) }\end{array}$ \\
\hline Average cooling load & $1 \mathrm{~kW}$ & $1 \mathrm{~kW}$ \\
\hline $\begin{array}{l}\text { Motor Power } \\
\text { (fans/air- } \\
\text { conditioning) }\end{array}$ & $\begin{array}{c}0.036 \mathrm{~kW} \text { (daytime) } \\
0.853 \mathrm{~kW} \text { (night-time) }\end{array}$ & $0.059 \mathrm{~kW} / 0.362 \mathrm{~kW}$ \\
\hline Yearly running hours & $\begin{array}{l}\text { Daytime: } 8 \text { h per day }(520 \mathrm{~h}) \\
\text { Nighttime: } 9 \text { h per day }(585 \mathrm{~h})\end{array}$ & $8 \mathrm{~h}$ per day $(520 \mathrm{~h})$ \\
\hline $\begin{array}{l}\text { Yearly energy } \\
\text { consumption } \\
\text { (daytime) }\end{array}$ & $18.67 \mathrm{kWh}$ & \multirow{2}{*}{$219.02 \mathrm{kWh}$} \\
\hline $\begin{array}{l}\text { Total yearly energy } \\
\text { consumption } \\
\text { (daytime and } \\
\text { night-time) }\end{array}$ & $517.67 \mathrm{kWh}$ & \\
\hline Electricity cost [27] & \multicolumn{2}{|c|}{$\begin{array}{l}\text { Day tariff }(8 \mathrm{~h}-24 \mathrm{~h}): \text { GBP } 0.189 / \mathrm{kWh} \\
\text { Night tariff }(24 \mathrm{~h}-8 \mathrm{~h}): \text { GBP } 0.098 / \mathrm{kWh}\end{array}$} \\
\hline $\begin{array}{l}\text { Yearly running cost } \\
\text { (daytime) }\end{array}$ & GBP 3.53 & GBP 41.4 \\
\hline $\begin{array}{l}\text { Total yearly running } \\
\text { cost (daytime and } \\
\text { night-time) }\end{array}$ & GBP 52.3 & GBP 41.4 \\
\hline
\end{tabular}

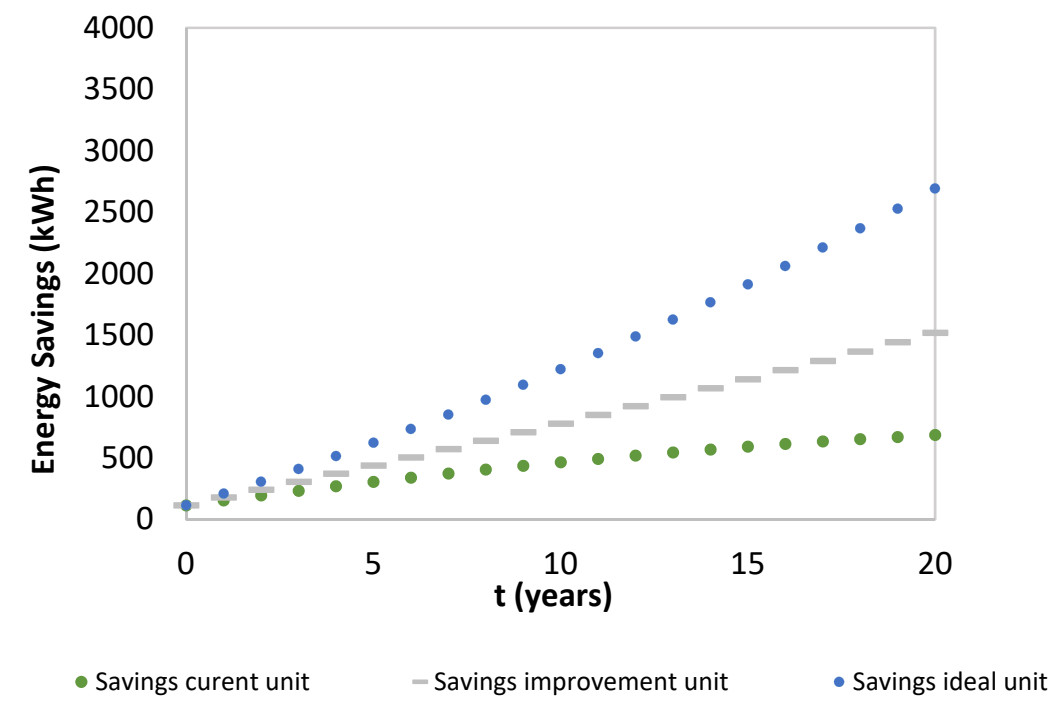

Figure 4. Energy savings for current air-multiple unit, improved unit and ideal unit. 


\section{Conclusions}

The scope of this research was to perform a techno-economic analysis and environmental benefits of a low-carbon technology (e.g., air-multiple PCM unit, previously studied and designed by the author) and a traditional air-conditioning (AC) unit for cooling and ventilating application. There is a lack of such analysis, specifically on the economic side of such upcoming technology, being crucial for industrial applications and for its uptake in the market.

The analysis has been performed to a case study, involving the space cooling of an office building in Portugal. Considering the occupancy of 20 occupants, for a fresh air flowrate of $700 \mathrm{~m}^{3} / \mathrm{h}$ and guaranteeing the comfort temperatures, the required cooling load and ventilation corresponded to $1 \mathrm{~kW}$. The capital, maintenance and running costs have been estimated for such cooling capacity of both systems. The labour costs and space requirements have not been considered, as similar costs were expected for both units. Regarding the capital costs, both present a similar cost, however, for the maintenance, the AC system presents a 4.5 times higher cost than the air-multiple PCM unit (mostly related with cleanliness of air filters) during their lifetime. Concerning the running costs (most impact on the overall costs), the study showed that air-multiple PCMs unit, during daytime, enabled a reduction in energy consumption (greater than 5,5 times) comparing to a conventional AC system. The proposed PCM unit, however, turns out compromised when considering the energy consumption linked to the charging of the PCMs during the night period. An analysis has been performed considering the whole lifetime of such units to evaluate the impact of a heat transfer improvement method (e.g., insertion of fins in PCM panels) on the running costs-the major costs of such units. Such method enables a greater heat transfer during solidification time and, consequently, a lesser air flowrate is required for its charging. The results show that such method can duplicate the energy savings of the current air-multiple PCM unit during its lifetime.

Looking at the environmental benefits, the air-multiple PCM units present several environmental benefits such as the non-use of refrigerants and disposal requirements, as well as the benefit of a better individual health conditions when compared to traditional ACs.

This study also showed that air-PCM units require, for any application, a combined analysis of charging (e.g., solidification) and discharging (e.g., melting) processes. In addition, if for instance, the charging period is achieved "passively" without energy consumption, then, consequently, the discharging (cooling) load will be more efficient or cheaper.

Funding: This research received no external funding.

Institutional Review Board Statement: Not applicable.

Informed Consent Statement: Not applicable.

Data Availability Statement: The data that support the findings of this study are available from the author, upon reasonable request.

Conflicts of Interest: The author declares no conflict of interest.

\section{References}

1. Konstantinidou, C.A.; Papadopoulos, A.M.; Lang, W.; Santamouris, M. Life cycle and life cycle cost implications of integrated phase change materials in office buildings. Energy Res. 2018, 43, 150-166. [CrossRef]

2. Abuelnuor, A.A.A.; Omara, A.; Saqr, K.M.; Elhag, I.H.I. Improving indoor thermal comfort by using phase change materials: A review. Int. J. Energy Res. 2018, 42, 2084-2103. [CrossRef]

3. Iten, M.; Liu, S. A work procedure of utilising PCMs as thermal storage systems based on air-TES systems. Energy Convers. Manag. 2014, 77, 608-627. [CrossRef]

4. Iten, M.; Liu, S.; Shukla, A. A review on the air-PCM-TES application for free cooling and heating in the buildings. Renew. Sustain. Energy Rev. 2016, 61, 175-186. [CrossRef]

5. ASHRAE. Handbook of Fundamentals; American Society of Heating, Refrigeration and Air Conditioning Engineers, Inc.: Atlanta, GA, USA, 2011. 
6. Saffari, M.; Gracia, A.; Fernández, C.; Cabeza, L.F. Simulation-based optimization of PCM melting temperature to im-prove the energy performance in buildings. Appl. Energy 2017, 202, 420-434. [CrossRef]

7. Cunha, J.P.; Eames, P. Thermal energy storage for low and medium temperature applications using phase change ma-terials-A review. Appl. Energy 2016, 177, 227-238. [CrossRef]

8. Agyenim, F.; Hewitt, N.; Eames, P.; Smyth, M. A review of materials, heat transfer and phase change problem formula-tion of latent heat thermal energy storage systems (LHTESS). Renew. Sustain. Energy Rev. 2010, 14, 615-628. [CrossRef]

9. Seeniraj, R.; Narasimhan, N.L. Performance enhancement of a solar dynamic LHTS module having both fins and multiple PCMs. Sol. Energy 2008, 82, 535-542. [CrossRef]

10. Chiu, J.N.; Martin, V. Multistage latent heat cold thermal energy storage design analysis. Appl. Energy 2013, 112, 1438-1445. [CrossRef]

11. Wang, P.; Wang, X.; Huang, Y.; Li, C.; Peng, Z.; Ding, Y. Thermal energy charging behaviour of a heat exchange device with a zigzag plate configuration containing multi-phase-change-materials (m-PCMs). Appl. Energy 2015, 142, 328-336. [CrossRef]

12. Mosaffa, A.; Ferreira, C.A.I.; Talati, F.; Rosen, M. Thermal performance of a multiple PCM thermal storage unit for free cooling. Energy Convers. Manag. 2013, 67, 1-7. [CrossRef]

13. Fang, M.; Chen, G. Effects of different multiple PCMs on the performance of a latent thermal energy storage system. Appl. Therm. Eng. 2007, 27, 994-1000. [CrossRef]

14. Tan, P.; Lindberg, P.; Eichler, K.; Löveryd, P.; Johansson, P.; Kalagasidis, A.S. Thermal energy storage using phase change materials: Techno-economic evaluation of a cold storage installation in an office building. Appl. Energy 2020, 276, 115433. [CrossRef]

15. Nattaporn, C. Energy and economic analysis of a building air-conditioner with a phase change material (PCM). Energy Convers. Manag. 2015, 94, 150-158.

16. Boccardo, L.B.; Kazanci, O.B.; Allerhand, J.Q.; Olesen, B.W. Economic comparison of TABS, PCM ceiling panels and all-air systems for cooling offices. Energy Build. 2019, 205, 109527. [CrossRef]

17. Mechouet, A.; Oualim, E.M.; Mouhib, T. Effect of mechanical ventilation on the improvement of the thermal perfor-mance of PCM-incorporated double external walls: A numerical investigation under different climatic conditions in Morocco. J. Energy Storage 2021, 38, 102495. [CrossRef]

18. Iten, M.; Liu, S.; Shukla, S. Experimental validation of an air-PCM storage unit comparing the Effective Heat Capacity and Enthalpy methods through CFD simulations. Energy 2018, 155, 495-503. [CrossRef]

19. Liu, S.; Iten, M.; Shukla, A. Numerical study on the performance of an air-Multiple PCMs unit for free cooling and ventilation. Energy Build. 2017, 151, 520-533. [CrossRef]

20. Decreto de Lei no. 28/2016D.R. no. 119, Série I, 2016. Available online: https://dre.pt/dre/detalhe/decreto-lei/28-2016-74774858 (accessed on 1 September 2021).

21. Matias, L. Desenvolvimento De Um Modelo Adaptativo Para Definição Das Condições De Conforto térmico Em Portugal; Dissertação Elaborada No Laboratório Nacional De Engenharia Civil Para a Obtenção Do Grau De Doutor Em Engenharia Civil, Instituto Superior Técnico, Universidade Técnica de Lisboa: Lisboa, Portugal, 2010.

22. Iten, M.; Liu, S.; Shukla, A. Experimental study on the thermal performance of air-PCM unit. Build. Environ. 2016, 105, 128-139. [CrossRef]

23. Iten, M.; Liu, S. Experimental Study on the Performance of RT 25 to be Used as Ambient Energy Storage. Energy Procedia 2015, 70, 229-240. [CrossRef]

24. Rego, F.C.; Rocha, M. Climatic Patterns in the Mediterranean region. Ecol. Mediterr. 2014, 40, 49-59. [CrossRef]

25. Aguiar, R.; Coelho, R.E. Manual de Instalação e Utilização do Software SolTerm-Versão 5; Laboratório Nacional de Energia e Geologia, I.P. Unidade de Análise Energética e Alterações Climáticas: Lisboa, Portugal, 2012.

26. Rubitherm Technologies GmbH, Germany, 2021. Available online: https://www.rubitherm.eu/ (accessed on 1 September 2021).

27. ERSE, Portugal. 2018. Available online: http://www.erse.pt/ (accessed on 1 September 2021).

28. Stritih, U. An experimental study of enhanced heat transfer in rectangular PCM thermal storage. Int. J. Heat Mass Transf. 2004, 47, 2841-2847. [CrossRef] 